удк: 930:159.953.2:341.485(=411.16):791.61

DOI: $10.26661 /$ zhv-2019-1-53-24

\title{
The Formation of Memory on Jewish People Genocide in the Soviet Cinematography
}

\section{V. Sakhno \\ Zaporizhzhia National University \\ oliasahno@ukr.net}

Key words: Second World War, Jewish people, genocide, cinema, propaganda.

\begin{abstract}
In the article, the influence of cinematography on the memory formation about Jewish people genocide is analysed. The propaganda purpose of filmmaking in the 1930s with the aim at a particular Jewish topic, its further prohibition in 1939 and screen comeback at the beginning of German and Soviet war is shown. Attention is drawn of the fact that during 1960-1970s, a great number of films did not meet the requirements of ideological consistency. The main distinction between the represented subject of European genocide in Soviet cinematography and the Western one is disclosed. An episodic and nonessential feature of Jewish topic in Soviet films due to the "Soviet character of war victims" is emphasised. The role of the Soviet cinematography in the formation of myth on the "Great Patriotic War" is mentioned.
\end{abstract}

\section{Формування пам'яті про геноцид єврейського народу у радянських кінофільмах}

\section{B. Сахно}

Запорізький національний університет

Ключові слова: Друга світова війна, єврейський народ, геноцид, кіно, пропаганда.
У статті аналізується вплив кіно на формування пам'яті про геноцид єврейського народу. Показано пропагандистську мету створення фільмів у 1930-х рр. $з$ наявною в них єврейською тематикою, подальшу їх заборону у 1939 р. і повернення на екрани з початком німецько-радянської війни. Акцентується увага на тому, що протягом 1960-1970-х рр. велика кількість стрічок не пройшла перевірки на ідеологічну витриманість. Висвітлено суттєву відмінність між представленням теми єврейського геноциду у радянському кіно, та на Заході. Наголошено на епізодичності, другорядності єврейської тематики у радянських фільмах, у зв'язку з пропагуванням «радянського характеру жертв війни». Показано роль радянського кіно у творенні міту «Великої вітчизняної війни».
Genocide of Jewish people is a special page in history which will be rethought by more than one generation. During a long time, the topic of the "Great Catastrophe" has been a subject of a great number of researches, which were dedicated to different aspects of that historical phenomena, for many scientists. It should be noticed that the main part of the researches was done by foreign historians due to the fact that this topic is rather developed in many foreign countries. However, in the last 20 years, Ukrainian historians have been actively participating in a comprehensive process of the investigation of this subject.

Unfortunately, there is a lack of academic resources relating to the Soviet cinematography concerning demonstration of genocide in particular. Speaking about foreign scientists who are working in the same field, cinema historian Jeremy Hicks should be noticed. He is a professor at the Queen Mary University of London. Mr Hicks has analysed particular Soviet films about the Holocaust, as documental as features films made in the USSR. In conclusion, he published the book "First films of the Holocaust: Soviet cinema and the Genocide of the Jews, 1938-1946." [2], which presentation was held in Moscow.

Within the context, the research "Phantom Holocaust: Soviet Cinema and Jewish Catastrophe." [1] which was written by Russian scientist and professor of Massachusetts University Ms 0. Gershenson should be mentioned. The book introduces the Western reader as non-realised scripts as movies that contain plots of Holocaust and was forbidden by the Soviet authorities: "Professor Mamlok" of 
1938 [12], "The Oppenheim family" of 1938 [13], "Swamp Soldiers" of 1938 [3].

Amid Ukrainian scientists, issues on the genocide of Jewish people in the Soviet cinematography was disclosed in a dissertation of A. Medvedovska [9]. Essentially, her research is dedicated to public opinion and the formation process of the Holocaust as a historical phenomenon. One of the objectives was to characterise how this subject influenced Soviet creative elite. Resource base contains related to the process of public opinion shaping, such as literature, media, memoirs, memorial objects, photographs as well as films.

Therefore, the topic of the genocide of Jewish people in the Soviet cinematography is rather small and was not very popular. In Ukraine, the issue used to be considered in the context of more general phenomena while most of the work was done abroad.

Due to the fact that the primary objective of cinematography as art was to create a certain idea, the field of study is still relevant and perspective. With reference to the Soviet cinematography, films about the Second World War had an enormous influence on historical memory formation.

The purpose of the research is to analyse the concept of Jewish people genocide in the Soviet period films which were considerably different from the ones made in Western countries. Analysis of the fact how Jewish people genocide was introduced in the films of the Soviet period gives more information and opportunities to look at the government policy as a whole regarding the creation of the "Great Patriotic War" myth through the prism of Soviet people sufferings.

It should be noticed that Jewish subject appeared in the Soviet cinematography in the 1930s, before the beginning of the Second World War. For example, such films as follows: "Professor Mamlok", "The Oppenheim family", "Swamps soldiers". Although it was not the main focus, anti-Semitism in Nazi German was shown. Above-mentioned films ware created with the aim of propaganda and can be characterised as "anti-Nazi" where main heroes were German people, German communists. Having signed Molotov-Ribbentrop Pact in 1939, films were removed from the release. However, with the beginning of the German-Soviet war in 1941, there was a need for these films again.

The scene of the Soviet Jews shooting firstly appeared in "Unbreakable" (1945) filmed by M. Donskyi [11]. The film was highly appreciated on the Venice Film Festival and even won an award. However, next year it was included in the list of forbidden films of the USSR.

At the same time, the subject of anti-Semitism was noticed in the movie "Ivanna" (1959) filmed by V. Ivanchenko [7]. The movie was filmed with the aim of anti-religious propaganda proliferation; the main storyline was around that topic. The film was quite successful and was not forbidden further. In one of the storylines, the Lviv ghetto where anti-Jewish action takes place is shown.

In 1965, a new documentary anti-fascist film "Ordinary fascism" produced by M. Romma was released [6]. The fact is that it was filmed on the basis of photographs founded in the Nazis, chronical materials which were excluded from the Third Reich archive and so on. In addition, the scenes about Jewish victims were mentioned.

The period of 1960-1970 is characterised by a great number of prohibition either literature or cinematography. To be released, a film had to path a long way of ideological consistency. During those years, a great number of films were created but never widely released.

In this context, a film of 1966 "Eastern Corridor" created by V. Vinogradov in the studio "Belarusfilm" [14]. The film was attributed to the cohort of anti-feature films. The main storyline depictures Belarus underground movement and patriotic propaganda. The film consists of a scene of mass elimination of Jews in the Minsk ghetto which was shown through sinking. However, it was strongly criticised and condemned by its naturalism, symbolism and went on to be forgotten at all [9, p. 84].

The film "Commissioner" produced by 0 . Askoldov [8], which was released in 1967, either was not approved by Soviet ideologists. A. Medvedovska mentioned that its disapproval was even stronger that V. Vinogradov's film due to the fact that it was written on the basis of a narration "In the town Berdychiv" by V. Grossman who considered to be anti-Soviet [9, p. 84]. The release of the film was dedicated to the 50th anniversary of the $0 c$ tober Revolution. Therefore, the plot should have included loyalty to revolutionary ideas.

By contrast, the filmed was far from "ideal" due to the fact that the main storyline was about a Jewish family that had experienced sufferings who became a personification of the whole people. One of the most impressive scenes is a symbolic march of Jews worn clothes with sewn ghetto stars. 0 . Askoldov was accused of ideological diversion, excluded from the party. as a result, his producer career was over. Moreover, the film was added to the list of forbidden. That was his the first and last work which unluckily was not presented to the public. 
Only after 20 years, during the Perestroika (Restructuring), there was a rehabilitation. At the end of the 1980s, the film won many international rewards and became the film of the year in FRG, GDR, Switzerland, Sweden, was ceremonially demonstrated in the US Congress.

The presence of Jewish storylines played an important role in the fortune of these films.

After changes of government policy towards the transparency and filling the gaps in 1985, the process of heated discussions of various taboo topics including Holocaust.

Produced by L. Horovets in 1990, the film "Ladies' Tailor" has become very popular [5]. There is a story about a Jewish family, the action takes place the day before shooting in Babyn Yar. The tragedy of Jewish people in occupied Kyiv in 1941 is shown through a tailor Isaak's family who have to run away in accordance with Nazis' declaration. Fear, uncertainty, thoughts about further life are emotions which the film is full with.

In fact, earlier in the Khrushchev period, plots of the Holocaust were demonstrated in the context, therefore particular attention was not paid to. This film is a vivid example of gradual return from those so-called dogmas.

Among many cinematographic examples, there are lots of those which remain as scripts only. Above-mentioned 0 . Gershenson carried out significant research in this area. The first script she managed to find is "I Will Live" written by a Jewish Poet D. Bergelson in 1941.

One more script, which was called "Gott mit uns" (translated from German and Yiddish into English as "God is with us", was written by Lithuanian producer. This is the story of a Lithuanian priest who saves and hides a Jewish boy. According to the researcher, it could have become an essential contribution to cinematography but Moscow did not approve the script [10]. In 2015, during the UN roundtable dedicated to the role of art in preservation memory of Holocaust, 0 . Gershenson took part. In her interview, she told that she had found a whole pile of such scripts in archives [15]. Consequently, further search in this direction could be rather successful.

With the help of analysis how the subject of the Great catastrophe was screened in the Soviet cinematography, conclusions concerning formation on Holocaust memory can be made. In this regard, there are significant distinctions between East and West. By contrast with the USSR, in Western countries, the subject of the Second World War considers through the prism of the Holocaust. The war as a phenomenon is inhumanity at first. Notably, the
Holocaust showed how inhumane people could be.

As in the USSR as in modern Russia, the tendency of the Second World War perception is exactly the opposite. The Great catastrophe does not have the same centre as the subject of war has. Millions of victims are not divided into ethnicity. In movies, which were shown in the Soviet period, the subject of Jewish genocide was not ignored, it was presented but in the context as a minor and invisible catastrophe. Murdering of Jewish victims was just like episodes. In the above-mentioned film "Ordinary fascism", where frames of a concentration camp, bodies of killed, personal things and so on, a voiceover does not inform a viewer who ethnically these victims were.

Since 1968 to Perestroika, the subject of Jews occurred under pressure of censorship. Moreover, in anti-German Soviet films producers avoided mentioning Nazi repressions. According to the review of 0 . Gershenson's book "The Phantom Holocaust", A. Fedorov characterises this situation as follows: "In the Soviet cinematography of the 1970s, a conundrum concerning Jews without Holocaust and Holocaust without Jews occurred" [16].

Among the reasons why in Soviet cinematography the Holocaust issue used to be avoided but partially represent the subject as well as did not use to underline Jews' belonging to victims, a scientist J. Hicks points out several explanations which are authorities fear of the anti-Semitic manifestation and internationalist propaganda of the country where there is no place for individual nations but only one Soviet people [4].

In the dissertation research, A. Medvedovska refers to C. Hitelmann, an American researcher, who explained that Soviet authorities were afraid of Jewish people being aware of their unique tragic faith during the war. Therefore, it would have been beneficial in national self-awareness of Jewish people that could have held to an assimilation problem. One more question is the collaboration of non-Jewish people [9, p. 19]

Consequently, the subject of the genocide of Jewish people in Soviet cinematography was not shown on a sufficient level. It can be explained with government policy directed towards propaganda of internationalism and the "Soviet character of war victims". A great number of scripts written during the Second World War was not made as they did not meet standards of social realism. Those films which succeeded in censorship showed the topic of the Grate catastrophe optionally without emphasising Jewish losses.

In comparison with the West where the Second 
World War is connected with the Holocaust at first, in the USSR and modern Russia, a politicised myth about the Great Patriotic War is still the only propaganda tool. Memory policy is based on the percep- tion of the war not through the prism of victims, as it is in the West, but through the prism of victory. This paradigm is extremely rooted and bred every year on the 9th of May.

\section{Джерела та література}

1. Gershenson 0. The Phantom Holocaust: Soviet Cinema and Jewish Catastrophe. New Brunswick: Rutgers University Press, 2013. 290 p.

2. Hicks Jeremy First films of the Holocaust: Soviet cinema and the Genocide of the Jews, 1938-1946. Pittsburgh: University of Pittsburgh Press, 2012. 300 p. - URL: https://books.google.com.ua/books?id=zn8e-7txTXQC\&printsec=

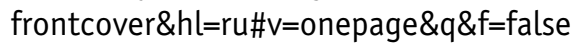

3. «Болотні солдати. Художній фільм.- 1938. URL: https://www.youtube.com/watch?v=4iz2o4Cwdig (дата звернення 20.03.2019).

4. Голокост у радянському кіно: про що не говорили? // BBS News|Україна. URL: https://www.bbc.com/ ukrainian/entertainment/2014/06/140619_jeremy_hicks_holocaust_ie_yg) (дата звернення: 17.03.2019).

5. «Дамський кравець». Художній фільм._- 1990. URL: https://www.youtube.com/watch?v=_f9txHNZl2c (дата звернення: 17.03.2019).

6. «Звичайний фашизм». Документальний фільм. 36 хв 22 с. до 8 хв. 50 с. - 1965. URL: https://www.youtube. com/watch?v=3XkYpjJT3fs (дата звернення: 18.03.2019).

7. «Іванна». Художній фільм. 344 хв 05 с. до 46 хв. 00 с. 1959. URL: http://kinoblog.tv/films/n2350/filmivanna.html (дата звернення: 17.03.2019).

8. «Комісар». Художній фільм. 3 год 31 хв 20 с. до 1 год.33 хв. 32 с. 1959. URL: https://www.youtube.com/ watch?v=LDemFDzX-u0 (дата звернення: 20.03.2019).

9. Медведовська А. Ф. Голокост в Україні в суспільній думці кінця XX - початку XXI ст. : дис. ... канд. іст. наук : спец. 07.00.01 Дніпропетровський. нац. ун-т ім. 0. Гончара. Дніпро, 2016. 239 с. URL: http://www.dnu.dp.ua/ docs/ndc/dissertations/D08.051.14/dissertation_58459fad28388.pdf

10. Невидимая катастрофа. Радио Свобода. URL: https://www.svoboda.org/a/25122148.html (дата звернення: 15.03.2019).

11. «Нескорені». Художній фільм. 343 хв 30 с. до 44 хв. 00 с. 1945. URL: https://www.youtube.com/ watch?v=te0mp-hdMgY (дата звернення: 15.03.2019).

12. «Професор Мамлок». Художній фільм. 1938. URL: https://www.youtube.com/watch?v=xBD1ijaY48M (дата звернення: 18.03.2019).

13. «Сім'я Оппенгейм. Художній фільм. 1938. URL: https://www.youtube.com/watch?v=UTUtVIRigr0 (дата звернення: 18.03.2019).

14. «Східний коридор». Художній фільм. 358 хв 53 с. до 1 год. 00 хв. 17 с. 1966. URL: https://www.youtube. com/watch?v=9SCgy4240Kc (дата звернення: 19.03.2019).

15. «Фантомный Холокост» в советском кинематографе. Новости 00H. URL: https://news.un.org/ru/ audio/2015/01/1026441 (дата звернення: 17.03.2019).

16. Федоров А.В. Советский кинематограф и еврейская катастрофа: взгляд из Америки. URL: http://people. umass.edu/olga/MyArticles/Fedorov\%20review\%20of\%20Phantom\%20Holocaust.pdf (дата звернення: 17.03.2019). 